\title{
Access and impact of micro credit on poverty alleviation among farmers in kirfi local government area of Bauchi State.
}

\author{
Emefesi; B.O and Yusuf; B \\ College of Agriculture, Department of Agricultural Extension and management \\ Bauchi, Bauchi state
}

\begin{abstract}
This study was conducted in order to examine the role micro-credit on poverty alleviation among femers in Kirfi Local Government area of Bauchi State. Survey approach was employed to collect data from the respondents sample was collected through cluster sampling technique from the accessible population such as cooperative groups, farmers associations, and woman groups who are mainly the beneficiaries of micro finance from nine villages. A total of 100 questionnaire ware administrated out of which ninety five (95) were retrieved and used for the purpose of analysis. Data collected was subjected to analysis by use of relevant statistical tools such as percentages, pie chart presentations and bar charts. The result shows that $42.1 \%$ of the respondent obtained their loan from Bank of Agriculture, $21.1 \%$ of the respondents indicated micro finance banks, another $21.1 \%$ of the respondent indicated cooperative societies, $10.5 \%$ of the respondent indicated relations, and $5.3 \%$ indicated neighbors as their main sources of credit facilities. The result indicates that $45 \%$ respondents identified improved purchasing power of farm implements as the major impact of micro credit on their poverty alleviation status, 23.2\% identified improved purchasing power of improved seed as their major impact of micro credit on their poverty alleviation level. The result also indicated that $36.8 \%$ of the respondents indicated improved feeding for their entire household as a result of the micro credit, $31.6 \%$ indicated increased purchasing power of household items while the remaining $31.6 \%$ indicated improved education of their children as the main impact of micro credit on their household. However, $47 \%$ of the respondents indicated that their major constraint in accessing loan is that there are no available Agricultural banks in their locality where they live, $21.1 \%$ indicated that there are bureaucratic bottlenecks that serve as a major constraint to their accessing loans from formal institutions. Forty seven point four percent (47.4)of the respondents indicated inadequate funds as their major constraint in accessing loans from informal institutions, while $15.8 \%$ indicated that short repayment period is a major obstacle to accessing loans from informal institutions. It is recommended that government operate Agricultural Banks in all the local government areas of the state for easy access of credit facilities to farmers, and should reduce the bureaucratic bottlenecks in the processing of the loans to farmers.
\end{abstract}

\section{Introduction}

Agriculture is a major contribution to Nigeria cross domestic product and small scale Farmers play a dominant role in this contribution (Rahiyi and Fakayode, 2009). But their productive and growth are hindered by limited access to credit facilities (Odoememen and Obinne, 2010).

Nigeria being a developing country and the most populous notion is sub-Saharan Africa, equally has the highest poverty rate. The 2006 National census gives Nigerian population at 140 million. However, 7.0 million of the population lives below poverty line out of the 7.0 million Nigerians living below poverty line $72 \%$ are spread across the 19 Northern states compared to 435 recorded in the 17 southern states. By implication, it means poverty is more pronounced in the northern states than the rest of the pants of the country (UK essays, 2014). Indeed, it is estimated that over 70 percent of Nigerians are classified as poor, and half of this number live in absolute poverty (World Bank, 2009 landes, 2010) poverty is particularly severe in rural areas, where up to 80of the population live below line the poverty line and with librated access to social services and infrastructures (Adam, 2007.liffledfied 2005) the Rural populace depends mainly on agriculture especially peasant agriculture for food and income (Albanese and on, woke,2014 .

According to Kudi (2009); he assented by citing Fos (1996) that "agricultural development is the foundation for economic development and the agricultural sector is undoubtedly the prime area of concern importance of this sector and the fact that $72 \%$ of Nigerian households which are engaged in agriculture, most of these farmers are wallowing in object poverty".

According to Ayegba (2013) he stressed the importance of farm credit by saying that it "plays a crucial role in agricultural and rural development as it enable farmers reap economies of scale, venture into new technologies and empower them to provide utilities for a wider market, While Adegeye and Ditto (1985) described agricultural credit as the process of obtaining control over the use of money, good and services in the present in exchange for a promise to repay at a future date. A look at the breakdown of the figure shows a steady increase in the micro credit outreach: from 7.6million in 1997 to 92 million in 2004 (UK essays, 2014). While 
the breakdown of the 92million is as follows: 81.5million were in Asia, 7million in Africa and the Caribbean (UK. essays, 2014) yet in Nigeria, the situation of the access to micro credit leaves much to be desired.

Considering the importance of agriculture to the Nigeria economy, various government (federal and state) have attempted implementing different programmers towards development the agricultural sector. Knowing full well that the agricultural sector is central to the economic activities in Nigeria contributing between $31-42 \%$ of gross domestic product (GDP) between 2005- 2008. (Ugbajah and Ogwumba, 2013) besides the provision of paid and self employment to over $70 \%$ of its population (CBN, 2005; CBN 2007; Fresh plaza, 2008; Okoji and Cheta 2008).

Some of the programmers introduced by government include:

a) Agriculture credit guarantee scheme fund (ACGSF).

b) Agricultural credit scheme

c) Agricultural credit support scheme

d) Nigeria Agricultural cooperative and rural Development bank (NACRDB)

e) National economic empowerment Development strategy (NEEDS) amongst others

\section{Agricultural Credit Support Scheme (ACCS)}

This scheme was established in 2006 for financing large agricultural projects such as management of plantations, cultivation, or production of crops, livestock, fisheries, farm machinery and live service (Ugbajah, 2013). It is an initiative of the federal government and the central bank of Nigeria with the full support and participation of the bankers committee (Ayegba, 2013) Access was introduced to enable farmers exploit the untapped potential of Nigeria's agricultural sector, reduce inflation, lower the cost of agricultural production (i.e. food items), generate surplus for export, increase Nigerians foreign earrings as well as diversify its revenue base. (Ayegba, 2013)

\section{Agricultural Credit Guarantee Scheme Fund (ACGSF)}

The Agricultural credit Guarantee scheme fund was established in 1978 using Decree 20 of 1978. Using Decree No. 20 of 1977. The fund is managed by the central bank of Nigeria. Between 1978 and 1989 when the government deregulated the financial system banks started shying away from ending to the agriculture due to the perceived risk. In the process of revving the scheme, some innovations were introduced such as:

- Interest Draw back

- $\quad$ Trust fund model

- The self- help group linkage banking

Interest draw back was meant to reduce effective barrowing rates without the complication of introducing dual interest rate regime or contradicting the existing deregulation policy of the government (AYEGBA 2013).

Trust fund is a needed framework for enhancing credit supply to the agricultural and rural sector of the economy. Under the model, oil companies, state, local government and non- government organization (N G O s) place fund in trust with lending bank to augment the small group- saving of the farmer as security for agricultural wars (AYEGBA, 2013).

\section{Commercial agriculture credit scheme (CACS)}

Commercial Agriculture credit scheme (CACS) was establish in 2009 by the central bank of Nigeria $(\mathrm{CBN})$ in collaboration with the federal ministry of Agriculture and water resources (FMA and WR) to provide finance for the country's agricultural value chain (production, process storage and marketing) the main objective of the scheme was to:

a) Increase output, generate employment, diversity Nigerian foreign exchange base, raise the level of foreign exchange aiming and provide input for manufacturing and processing on sustainable bases.

b) Reduce the cost of credit in agriculture production.

c) Enhance national food security.

d) Fast- track the development of the agriculture sector of the Nigerian economy (AYEGBA, 2013).

The borrowing rate is $14 \%$ with the central bank of Nigerian (CBN) while the borrow pay $8 \%$ at repayment. However, access to micro constrain militating against rural farmer agriculture production (IDACHEBA 2006 ANAMBARA STATE GOVERNMENT, 2008). Yet agriculture credit enhances productivity and promote standard of living by breaking scale farmer (Ugbaja, and Chidebula 2012). According to Odeomenen and Obinne (2010) one of the reason for the decline in the conurbation of agricultural to the Nigerian economy is the lack of a stable national credit policy and paucity of credit in situation which can assist famers. 
In order to compliant the effort of the government, since 1980s non-government organization (NGOS) have emerged in Nigerian to champion the course of the micro and rural entrepreneur with a shift from the supplied approach to a demand driven strategy. The number of NGOS involve in micro finance activities has increase in recent joins due largely to the in ability of the service needed by the low income group and the poor, and the development partner among others as noted Agbeze and Onwuka (2014)

\section{Statement of the problem}

The millennium development goals of minting extreme poverty by the year 2015 seem to be a mirage looking at the poverty profile of farmers in the country. Despite several government intervention programs to tack poverty the number of people living below poverty line seem to be on the increase as the year go by.

\section{Objective of the study}

The general objective of this study is to examine the access and impact of micro credit on poverty among famer in Nkirfi local government of Bauchi state. The specific objectives are:

A) To examine the access to credit by farmer in Kirfi Local government area.

B) To determine the impact of micro credit on the house hold and agriculture enterprises engage upon by the farmer in the study area.

C) To identify the constraints faced by the famer in accessing credit facilities in the study area.

\section{Methodology}

The study was conducted in Kirfi L. G .A Kirfi is a local Government Area of Bauchi state, Nigeria bordering Gomez state in the East. Its head averts is kirfi town (kirfin kasa). It has an area of 2, $371 \mathrm{~km} 2$ and a population of 147,618 at the 2006 census. (Wikipedia. 2014) The North easterly line of equal latitude and longitude passes through the local Government Area I.e between latitude $9^{\circ} 3^{\prime}$ and $12^{\circ} 3^{\prime}$ North and longitudes $8^{\circ} 50^{\prime}$ and $11^{\circ}$ east. (Wikipedia, 2014)

Main daily temperatures range from $29.2^{\circ} \mathrm{c}$ in July and August to $37.6^{\circ} \mathrm{c}$ in March and April. The mean daily minimum ranges from about $11.7^{\circ} \mathrm{c}$ in December and January to about $24.7^{\circ} \mathrm{c}$ in April and May. Humidity ranges from about twelve percent $(12 \%)$ in February to about sixty eight percent $(68 \%)$ in August. The rainy months are May to September, when humidity ranges from about 37 percent to $68 \%$. Monthly rain fall ranges from $0.0 \mathrm{~mm}$ in December and January, though only traces of less than 0 . mm in February and November, to about $343 \mathrm{~mm}$ in July. On set of the rains is often in March, while they end virtually by October. Radiation is fairly even throughout the year, ranging from about $11.3 \mathrm{~mm}$ in July to about $18.7 \mathrm{~mm}$ in April, even though it is relatively highest in March,, April and may. While evaporation ranges from $2.4 \mathrm{~mm}$ in July and August to about $15.7 \mathrm{~mm}$ in March, with the month of January being the period of greatest evaporation (On line Nigeria, 2014).

Survey approach was employed to collect data from the respondents sample was collected through cluster sampling technique from the accessible population that's constitute small scale farmers such as cooperative groups, farmers associations, and woman groups who are mainly the beneficiaries of micro finance from the following villages: Gawo, kirfin gasa, cheledi, wuro, Madaki, zamani Bukakko, Bedoji, Baba, Badara, Guyaba, Sindigawo. Data collected was subjected to analysis by use of relevant statistical tools such as percentages and pie chart presentations.

\section{Result and Discussion}

Figure 1 indicates that $42.1 \%$ of the respondents identified bank of Agriculture as their major source of micro credit in their community, twenty one point one percent $(21.1 \%)$ of them identified cooperative societies as their major sources of micro credit, another twenty one point one present $(21.1 \%)$ accessed micro credit from micro finance banks, ten point five percent (10.5\%) accessed microcredit from relations and five point three percent (5.3\%) accessed micro credit from neighbors. This result disagrees with Ayegbas (2013) result which stated that private money lenders constitute $53.33 \%$ of sources of micro credit among rural farmers in Nigeria. By implication if the government will make accessible Bank of Agriculture to rural areas of Nigerian and the study area in particular, there shall be increase accessibility of the loans to rural farmers. Also, government need to sensitize rural farmers through radio broadcasting about the availability of Bank of Agriculture in serving their purpose of collecting loans for agricultural and other purpose at a lower interest rate. 


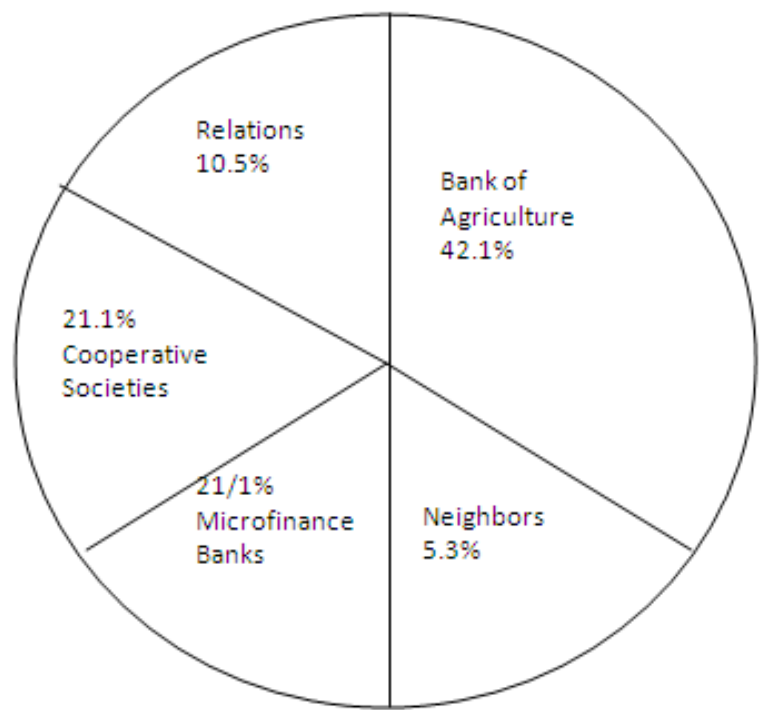

Figure 1: A pie chart indicating the accessibility of micro credit of respondents

\section{Impact of micro finance on Farmers poverty alleviation status}

Table 1 indicates that $45 \%$ of the respondents identified purchase of farm implements as the main impact of microcredit on their agricultural enterprise, twenty three point two percents (23.2\%) identified purchase of improved seed as the major impact/ use of the micro on their agriculture enterprise.

In the same vein, thirty six point eight percent $(36.8 \%)$ of the respondents identified improved feeding as the major impact of micro credit on their households, while thirty percent $(30 \%)$ indicated increased purchase household items such as chairs, motorcycle, kitchen utensils and bedding, another thirty percent $(30 \%)$ of the respondents identified improved educational status of their children since they were able to sponsor their children in school better compared to before. This result aggress with Kudi et al (2009) which studies the impact of UNDP micro finance programme on poverty alleviation among farmers in selected local government areas of Kaduna state. In their result the fund that $48.1 \%$ of the respondent identified that the improvement very much twenty five point nine percent $25.9 \%$ also indicate much improvement finding pendent identified s training in school was one $40.5 \%$ the impact of the microfinance house hold income in a similar light indicated of the Kudi et al (2009) agrees of Kudi el al of this study chemical and cost of hired labor in selecting Local government areas of Kaduna state after collecting the loans. According to state to Kudi et al (2009) the result of their study indicate that the equation respondent cross margin ad other purpose at lower in interest rate rose from 48, 609.30 to $189,187.00$ for those who participate in loan collection. This implies that micro credit programmed had a positive impact on the of respondent which show on the famer income.

Table 1: Impact Of Micro Credit On Famer Poverty Alleviation Status

\begin{tabular}{rll} 
Impact on agricultural enterprise & frequency & $\%$ \\
\hline - Purchase of improve seeds & 22 & 23.2 \\
- Purchase of farm implement & 43 & 45 \\
- Improve post harvest tool & 20 & 21.1 \\
- Improved hiring of farm tools & 10 & 10.5 \\
\hline Total & $\mathbf{9 5}$ & $\mathbf{1 0 0}$ \\
\hline
\end{tabular}

\section{Impact on house hold}

- Improve feeding

- Increased purchase of house item

- Improved education of children
35

30

30
36.8

31.6

31.6

\section{Constraints faced by farmer in accessing micro credit facilities}

Figure 2 show that $47.4 \%$ of the respondent identified usability of agriculture bank in their community as the major challenge to their accessing micro credit in their locality, twenty one point one percent $(21.1 \%)$ of the respondent identified bottle necks as a major challenge which and up in late approach at the find from micro finance institution. While $47.4 \%$ of the respondent identified inadequate credit found as a major challenge collection loan informal micro finance institution governmental organization, money lender private e.t.c point 
three $(26.3 \%)$ of the respondent indentified high interest rate associate with collecting loans finance institution this study après small loan in Kaduna but it $77.8 \%$ who benefit from the micro credit but it disagreed with Ayegba (2013) studies which identified late approval of loan in his study area (rural farmer in Nigerian) by $43.33 \%$ of the respondent another challenge identified by the $15.89 \%$ of the respondent with the formal micro finance institution is the short repayment period which does rot allow them make full use of the money before the repayment. This agree with Kudi et at (2009) result which also identified tenure of loans repayment too short by $5.9 .3 \%$ of the respondent in their study of selected local government area of Kaduna state. Despite the major challenge of not the rural farmer more to the in search for the loan from the bank, and some of them from Fadama programmers. This implies that the formal micro credit institution still have higher and better advantages for rural farmers over the information microfinance institutions whose challenge outweigh benefits. If government can make agricultural banks more accessible, the rural farmer's poverty alleviation status will increase putting into consideration the unique agricultural financing mandate compared to other financial institutions.

\begin{tabular}{llcc}
$\begin{array}{l}\text { Constraints faced by farmers in accessing micro credit facilities } \\
\text { Constraints } \\
\text { frequency }\end{array}$ & \% \\
\hline- & High interest rate & 7 & 7.4 \\
- & Late release of funds & 15 & 15.8 \\
- & Bureaucratic bottlenecks & 20 & 21.1 \\
- & Guarantor problem & 8 & 8.4 \\
- & No agric bank in community & 45 & 47.4 \\
\hline TOTAL & $\mathbf{9 5}$ & $\mathbf{1 0 0}$
\end{tabular}

\begin{tabular}{lllc}
\multicolumn{2}{l}{ Constraints } & Frequency & $\mathbf{\%}$ \\
\hline- & Inadequate funds & 45 & 47.4 \\
- & Short repayment period & 15 & 15.8 \\
- & Guarantor problem period & 7 & 7.4 \\
- & Sentiments & 3 & 3.2 \\
- & High interest rate & 25 & 26.3 \\
TOTAL & $\mathbf{9 5}$ & $\mathbf{1 0 0}$
\end{tabular}

\section{Conclusion}

From the result above, it is clear that micro credit Facilities have positive impact on rural farmers' poverty alleviation status. Most of the rural farmers in the study area have demonstrated that micro credit had position impact on improved purchasing power of farm implements, increased purchasing power of improved seed, improved feeding in their households, training of their children in school, buy household item such as seats and motorcycles. However, despite the enormous benefit of microcredit on farmers' income, challenges such as unavailability of Agricultural banks in their locality, bureaucratic bottlenecks and late release of founds are associated with formal microfinance institution. Also, farmers face challenges with informal institutions that provide microcredit such as inadequate funds and short repayment periods.

\section{Recommendations}

Therefore based on the finding of this study the following recommendations are made:

1) The operation of microcredit facilities should be extended to rural farmers in order to help alleviate their poverty status; and increase their agricultural productivity.

2) The bureaucratic bottleneals (processing of application for loan ) by formal microfinance institutions should be reduced

3) High interest rate charged by informational microfinance institution like private organization and nongovernmental organization should be reduced to make the farmers feel position impact of the micro credit.

4) Informal microfinance institution in particular should increase the amount of ioan given to farmers such as to increase agricultural productivity thereby reducing poverty among rural farmers.

\section{References}

[1]. FOS (1996). Federal office of statistic National Agricultural sample census (1995) (994) November_pp 22-32

[2]. Agbacze, E.K and on wuka, 1. 0 (2014). Impact of Micro -credit on poverty Alleviation in Nigeria- the case of Enugu East Local council. International Journal of Business and management Review Vol. 2 (1) pp 27 -51. Retrieved from http:// www Ea journals. Org (---) impact. Of -micro-credit-on-poverty-Alleviation-on 16/7/2014 at 9:24am

[3]. U K essays (2014) participation in micro credit and poverty Alleviation in Nigeria. Retrieved from http: 11 www.uk essays. Com $>$ Essays $>$ marketing on 16/7/2014 at 9: 37am. 
[4]. Central Bank of Nigeria (C B N) (2005). The Real sector C B N Annual Report and statement of Account for the year ended $31^{\text {st }}$ December, 2005. C B N publication, Abuja, Nigeria.

[5]. Central Bank of Nigeria (C B N) (2007). Domestic output C B N Statistical Bulletin 2007 CBN Publication, Abuja, Nigeria.

[6]. Wikipedia (2014). Bauchi state. Retrieved from en. Wikipedia.org (wiki) Bauchi state

[7]. Foin, D . N (2007). Sources \& Accessibility of Credit to Farmers for Agricultural financial in Makarfi local Government Area of Kaduna state. Saman Journal Of Information studies. Vol 7 (2) pp 34-38. Retrieved from http:// www. Ajol. Into index. $\mathrm{Php} / \mathrm{sjis} /$ article/ download/40607/ 8140 on $2 / 8 / 14$ by $11: 54$.

[8]. Idachaba, F .S (2006) Repositioning Nigeria agriculture to Realize Millennium Development Goals. Whether Nigeria is the Obasanjo Reform Agenda? Invited Keynote paper delivered eat the $40^{\text {th }}$ Annual conference of the Agricultural society of Nigeria at N R C R I Umudike $17^{\text {th }}$ October pp. 1-20.

[9]. Ugbajah, M.0 and Ugwumba c (2013) Analysis of micro credit as a veritable fool for poverty Reduction among Rural farmers in Anambra state, Nigeria. Discourse journal of Agriculture and Food sciences. Vol 1 (10):152-159. Retrieved from http: 11 www.resjournals. Org /JAFS/PDF/2013/OCT/Ugba'jah-and-Ugwumba. Pdf on 16/7/14 at 9: 26 am.

[10]. Ugba'jah. M . O and chidebelu, S (2012). Comparative Analysis of Access to financial services by Rural farmers in Anambra state Nigeria. International journal of Applied Research Technology Vol 1 (7).

[11]. Kanji N. and Cheta, 1 (2008). Nigeria Agriculture public Expenditure Review. Nigeria strategy support programme brief NO. 2 International food policy Research Institute, Abuja, Nigeria's

[12]. Odoemenem, I .U and Obinne, C . P .O. (2010). Assessing the factors influencing the utilization of Improved cereal crop production Technologies by small scale farmers in Nigeria. India 3 (1): 80-183.

[13]. Adegeye, A .J; and Ditto, J .S (1985). Essentials of Agricultural Economics. Impact publishers, Nigeria Limited, Ibadan.s

[14]. Rahji, M . A. Y; and Fakayode, S .A (2009). A multinomial Logit analysis of Agricultural credit Rationing by Commercial Bank in Nigeria. International Research Journal of Finance and Economics 24 (91) Retrieved from http: 11 www.evro journals. Com finance 